\title{
BDA AGMs
}

The Branch AGM of the Essex Branch will take place on Wednesday, 10 April 2019 at Writtle College, Writtle, Chelmsford, Essex CM1 3RR, as part of the Joint Study Day on 'core' CPD topics. The meeting begins at 13.00. For details about the event and how to book, visit https://www.bda.org/ events/branches-sections/Pages/essexbranch-wednesday-10-april-2019.aspx.

The Branch AGM of the Southern Counties Branch will take place on Thursday, 25 April 2019 at the East Sussex National Resort, Little Horsted, Uckfield, East Sussex TN22 5ES. The meeting begins at 18.00 . For details of the event and to book, visit https://www. bda.org/events/branches-sections/Pages/
Southern-Counties-Branch-AGM-25-

April-2019-East-Sussex-National-.aspx. The Presidential dinner follows the AGM, with this year's conference Making endodontics predictable in practice starting at 09:00 on Friday, 26 April 2019. To book, visit: www. bda.org/southerncounties.

The next Annual General Meeting of the BDA Benevolent Fund takes place on Thursday, 13 June 2019 at 15.30 at 64 Wimpole Street, London, W1G 8YS. The Benevolent Fund Trustees have reviewed their governing document and are proposing to bring it up to date, clarify a number of areas, and ensure the organisation is efficient and fit for the future. The Trustees will put forward various recommendations and amendments to the charity's governing document (the 'Rules') including to the structure of the Board and the process of recruitment of Trustees, changes to the membership by creating an additional 'Partnership' category, to open membership up to some beneficiaries and donors who are not currently BDA members, and some administration and procedural changes such as allowing those who cannot attend meetings to vote remotely. During the meeting, attendees will be able to vote on these proposals. For more information or to RSVP to attend the meeting, visit www. bdabenevolentfund.org.uk, call 0207486 4994 or email administrator@dentistshelp. org. The organisers have asked people intending to come to confirm their attendance by 13.00 on Monday, 3 June 2019.

\section{Almost $60 \%$ of children aged one to four did not see NHS dentist last year}

Nearly six in ten children (57.7\%) aged one to four years failed to see an NHS dentist in 2018 , according to official NHS Digital data. ${ }^{1}$

The new data published on 21 February 2019 showed that 4.9 million children did not attend a dentist last year in England, including $57.7 \%$ of the $1-4$ year-olds, or around one million of that age group.

Overall in the 12 months prior to 1 December 2018, seven million children were seen by an NHS dentist, which was $58.6 \%$ of the child population while 22 million adults patients saw an NHS dentist in the 24 months prior to December 2018 just $50.4 \%$ of the adult population.

Responding to the figures, the BDA said that tackling tooth decay needed more than the 'token gestures' made so far by the government.

The BDA said it had long advocated that England follow the lead set by devolved governments, including bringing supervised brushing to schools and nurseries as part of programmes such as Childsmile (Scotland) and Designed to Smile (Wales).

Henrik Overgaard-Nielsen, Chair of General Dental Practice at the BDA, said: 'Any government that claims to value prevention should not be letting nearly five million children miss out on free check-ups.

'The UK has pioneered polices that are transforming children's oral health. While countries from Chile to Israel are seeing the benefits, kids in England have been left with a second class system, without a penny of new investment behind it.'

Analysis of the NHS Digital data carried out by the Faculty of Dental Surgery (FDS) at the Royal College of Surgeons showed that overall, $41.4 \%$ of children aged 0 to 17 years, did not attend an NHS dentist appointment last year while around a third (32.7\%) of children aged five to nine years did not see an NHS dentist and $27.6 \%$ of 10 to 14 -year-olds also failed to see an NHS dentist during the year.

The FDS recommends parents and carers should register children with the dentist as soon as their first teeth appear and schedule their first check-up by the age of one, followed by children seeing the dentist at least once every 12 months, in line with guidance from the National Institute for Health and Care Excellence (NICE).

Responding to the new figures, Professor Michael Escudier, Dean of the FDS said:
'It's disappointing that nearly six in ten of 1 to 4 -year-olds did not see an NHS dentist last year.

'Children who experience early childhood tooth decay are much more likely to develop subsequent problems, including an increased risk of further decay in both their baby and permanent teeth.

'It's so important that a child's first interactions with the dentist are for simple check-ups rather than more serious treatment. Just getting a child into the habit of opening their mouth for a dentist to look at their teeth is useful practice for the future. FDS strongly advises that children have their first check-up before they turn one.'

Steve Preddy, Clinical Director and dentist for Bupa Dental Care said: 'Children's oral health is so important, and we share the desire to see more supervised tooth brushing sessions taking place in nurseries and primary schools.'

\section{References}

1. NHS Digital. NHS Dental Statistics for England 2018-19, Second Quarterly Report. 2019. Available at https://digital.nhs.uk/data-and-information/ publications/statistical/nhs-dental-statistics/quarter-2-2018-19 (accessed February 2019). 